\title{
INTERNATIONAL MONETARY FUND AND EAST ASIA: DEVELOPMENTS, CHALLENGES, AND LESSONS LEARNED
}

\author{
Maksym Kulbida ${ }^{1}$ \\ Institute of International Relations, National Aviation University, Ukraine
}

\begin{abstract}
The article demonstrates that during the extended period of cooperation, the IMF's activities have had both positive and negative impact on the development of economies of the East Asia region. On the one hand, the IMF initiated and supported in-depth reforms that formed a solid basis for sustainable development and growth of countries of the region. On the other hand, the IMF failed to achieve positive outcomes in some specific important areas mostly because of its unbalanced policies and due to disregard to specific needs of particular countries of the region. Furthermore, the IMF failed to properly discharge one of its main mandates to effectively predict, address, and overcome international financial crisis tendencies and processes that emerged from the fragility and the lack of sustainability of the global liquidity system at the regional level, and in particular during the Asian crisis of 1997-98. The IMF's failures led to a significant decrease of cooperation with the East Asia region and gave rise to the IMF stigma and subsequent regionalism processes. Although quite uncertain, any further cooperation may only be carried out on a new basis with due consideration of the specificity of the region and the particular countries. Methodology. The author provides first, based on the IMF's official statistics and data, an analysis of the cooperation between the IMF and the East Asia region in order to identify main achievements and failures and then explores possible forms of further cooperation with due regard to all stakeholders' interests and needs. The author aims to demonstrate, based on the IMF's experience in East Asia, that cooperation between the IMF and particular countries or regions is a complex and challenging process, which most often involves the need to give due consideration to various important factors, including country-based specificities and risks of reluctance to the IMF's activities. Results. It is shown that despite the IMF's several failures in East Asia the cooperation was, from long-term perspective, beneficial for the countries of the region, and that it is in the best interests of all stakeholders to find ways for further cooperation although on a new basis in order to ensure sustainable growth and to be able to effectively face eventual financial crises.
\end{abstract}

Key words: IMF, East Asia, ASEAN+3, regionalism, CMIM, AMRO.

JEL Classification: F33, F36, F55

\section{Introduction}

Since the last decade, East Asia region has become a global economic development driver not only because three countries of the region China, Japan, and Korea are amongst 12 largest economies in the world, but also and more importantly because of an increased number of countries with the fastest rates of economic growth. Dynamic economic development of the region as a whole significantly increases the share of world GDP. According to the IMF, the average annual growth rate of real GDP in East Asia region, including China and ASEAN-5, amounted to 5.2\% in 2017 (IMF, 2017). The World Bank predicts economic growth of the economies of East Asia region of 5.7\% in 2018 (World Bank, 2016), which is most likely to be achieved given expected high growth rates of China's economy (6.8\% in 2017).

According to the Asian Development Bank (ADB), investment demand for infrastructure projects in Asian countries amounts to 26.2 trillion US dollar with the need of 1.7 trillion US dollars annually for the period of 2016-2030 (ADB, 2017). Nevertheless, given this extremely high demand, any unconsolidated efforts of international financial institutions (IFIs) either global such as the IMF and the World Bank or regional such as $\mathrm{ADB}$ will not be sufficient to meet with their own resources the investment needs in the region (Svedentsov, 2017). This gives rise to the need for combined efforts by all stakeholders, including both the IFIs and respective countries. In this regard, most East Asian countries have since years demonstrated 
reluctance to any of the IMFs activities in the region mostly to the IMF's stigma effect after the Asia crisis that relates to both a mark of disgrace and a set of negative beliefabout a country's economic situation (Andone and Scheubel, 2017). Recent developments of international economy have given rise to the establishment of the so-called "new global economic order" which is grounded on two main factors, namely technological changes and tendencies towards general economic liberalization. Moreover, the global economy has also recently known a change in the balance of power, with the growing role of developing countries, in particular, East Asia emerging markets. The rapid growth of the East Asia region's economy together with the increased expansion of Asian transnational corporations onto the world markets, which demonstrate a high level of their competitiveness make the region one of the world most promising economic powers. That being said, at present, East Asia is one of the engines of world economic development and international economic relations (Arapova, 2015).

How and to which extent could the IMF enhance or at least maintain its presence in East Asia and more specifically overcome stigma it has since for a while suffered from in this region?

\section{The IMF's experience in East Asia countries: between achievements and failures}

Asia's economic development and subsequent growth date back to the end of the Second World War. Japan was the first country wherein economic growth began. In the 1960s, other countries such as Hong Kong, Korea, Singapore, and Taiwan, which are also known as "Asian tigers", clearly showed signs of economic recovery and significant growth with an orientation to foreign markets (Berendser, 2013). The course was shortly followed by other countries of the region - Indonesia, Malaysia, and Thailand. More recently, China and India jumped up in their economic development mainly because of the revision of their traditional methods of gradual liberalization. Trade was amongst major factors determining such growth; insofar trade has itself contributed to the processes of industrialization, based on the dynamics of comparative advantages that have shifted from the agrarian sector to the labour-intensive manufacturing industry, and more recently in more capital-intensive industries with highly skilled labour. This model of industrialization further contributed to accelerating economic growth with social improvements - creating new jobs and raising wages. Thus, in 1990 Asia's share in the world economy was $23.2 \%$, while in 2017 it exceeded $62 \%$. To date, two countries in East Asia region make up slightly less than $50 \%$ of world economic growth. Indeed, China's share amounts to $34 \%$ and India's share amounts to $13 \%$ of the global economic growth share.
The IMF began its activities in East Asia in the 1950s with the allocation of first arrangements to Japan. Subsequently, the Fund was involved in at least two more directions in the region. Firstly, the Fund provided technical assistance to the countries of the region in several areas, in particular, regarding the conduct of monetary policy. A number of countries such as Cambodia, Laos, and Vietnam continue to receive significant technical assistance from the Fund, in particular, in the areas of taxation, customs, and tax administration, the balance of payments management, central bank operations, banking supervision, monetary policy, and other areas.

Secondly, the IMF provided financial assistance through its arrangements to the countries of the region, mostly in the 1990s. East Asia's countries continued to benefit from the Fund's financial support even after the contradictory measures taken by the Fund with regard to the region at the course of the crisis in the late 1990s.

Table 1 below provides an overview of the IMF's financial assistance to East Asian countries since the 1980s.

Table 1

IMF arrangements in East Asia, 1980-2017

\begin{tabular}{|c|c|c|c|}
\hline Country & $\begin{array}{c}\text { Type of } \\
\text { arrangement }\end{array}$ & Period & $\begin{array}{c}\text { Amount drawn } \\
\text { (in millions of SDR) }\end{array}$ \\
\hline \multirow{2}{*}{ Cambodia } & ESAF/PRGF & $1999-2003$ & 58.50 \\
\hline & ESAF & 1994-97 & 42.00 \\
\hline \multirow{2}{*}{ China } & SBA & 1986-1987 & 597.73 \\
\hline & SBA & 1981 & 450.00 \\
\hline \multirow{3}{*}{ Indonesia } & EFF & $2000-03$ & $3,638.00$ \\
\hline & EFF & $1998-2000$ & $3,797.70$ \\
\hline & SBA & $1997-98$ & $3,669.12$ \\
\hline \multirow{4}{*}{ Korea } & SBA & $1997-2000$ & $14,412.50$ \\
\hline & SBA & $1985-87$ & 160.00 \\
\hline & SBA & $1983-85$ & 575.78 \\
\hline & SBA & $1981-82$ & 121.69 \\
\hline \multirow{4}{*}{ Laos } & PRGF & $2001-05$ & 18.12 \\
\hline & PRGF & $1993-97$ & 35.19 \\
\hline & SAF & $1989-92$ & 20.51 \\
\hline & SBA & $1980-81$ & 14.00 \\
\hline \multirow{7}{*}{ Philippines } & SBA & $1998-2000$ & 783.23 \\
\hline & EFF & 1994-98 & 791.20 \\
\hline & SBA & $1991-93$ & 334.20 \\
\hline & SBA & $1986-88$ & 198.00 \\
\hline & SBA & $1984-86$ & 403.00 \\
\hline & SBA & $1983-84$ & 100.00 \\
\hline & SBA & $1980-81$ & 410.00 \\
\hline \multirow{4}{*}{ Thailand } & SBA & $1997-2000$ & $2,500.00$ \\
\hline & SBA & $1985-86$ & 260.00 \\
\hline & SBA & $1982-83$ & 271.50 \\
\hline & SBA & $1981-82$ & 345.00 \\
\hline \multirow{3}{*}{ Vietnam } & PRGF & 2001-04 & 124.20 \\
\hline & ESAF & $1994-97$ & 241.60 \\
\hline & SBA & 1993-94 & 108.80 \\
\hline
\end{tabular}

Source: IMF data, wherein ESAF/PRGF - Enhanced Structural Adjustment Facility/Poverty Reduction and Growth Facility; EFF Extended Fund Facility; SAF - Structural Adjustment Facility; SBA Standby Arrangement. 
Thus, Table 1 demonstrates that the countries of the region significantly intensified their cooperation with the IMF during the period of the crisis of the 1990s that was mostly due to the process of globalization. In particular, it appears that countries such as Indonesia, Korea, and Thailand had benefited from the largest borrowing rates within with the most popular credit lines, namely SBA, which is typically aimed at addressing short-term balance of payments issues, and EFF, which is commonly used in order to tackle medium and longterm problems with the aim to stimulate the region's economies towards the implementation of necessary in-depth reforms.

However, the IMF's activities in the countries of the region during the crisis period were somehow ambiguous and were and are still heavily criticized. Thus, some economists argued that the Fund intervened in areas beyond its competence (Calomiris, 1998), while others stressed that the Fund promoted an unfriendly market policy in the region (Radelet and Sachs, 1998). Most of them criticized the excessive duration of the crisis, as well as the price that was paid for its handling. Allegations were also made as to political nature of the Fund's decisions (Feldstein, 1998).

The Asian financial crisis of 1997-98 is often flagged when analysing the policies and activities of IFIs in different parts of the world. Although it emerged as the continuation of the crisis processes in Latin America, it raised a number of new issues related to globalization and IMF policies. Thus, since that time, the IMF has been typically criticized for applying policy resulting in an increase in poverty and the gap between rich and poor people in East Asia region (King, 2001).

According to Shinji Takagi, the confirmed gaps in the IMF's policy in the region during the crisis were as follows: (i) the inability of the IMF to predict the vulnerability of national economies, in particular, in Indonesia and Korea;

(ii) the IMF's lending arrangements were unsuccessful, in particular, regarding fiscal policy;

(iii) the IMF required structural changes in areas that were not relevant to the resolution of the crisis, in particular, in Indonesia and Korea (Takagi, 2016).

Nevertheless, an analysis of the dynamics of GDP in the East Asia countries which have genuinely benefited from the IMF's assistance from the pre-crisis period to date, fairly demonstrates that the GDP of these countries has shortly increased and subsequently being relatively steady. In the early 2000 s, economies of the region began showing a significant revival as regards main indicators of economic performance. Flexibility and rapid recovery of East Asian economies during the last World Financial Crisis were to confirm the meaningfulness of reforms triggered 15 years ago under the IMF's guidance and support (Figure 1).

Despite its long-term achievements in East Asia region, it can, however, be fairly argued that the IMF failed to properly meet its function as a global regulator of international economic relations. Indeed, the IMF failed to effectively predict, address, and overcome international financial crisis tendencies and processes that emerged from the fragility and the lack of sustainability of the global liquidity system at the regional level. At the same time, the IMF seems to have learned from the Asian financial crisis. In particular, the Fund realized that in order to be able to effectively tackle structural economic issues, the more balanced and well-considered and selected measures should be implemented so as to give due consideration to specific needs of particular countries of the region. Furthermore, the Fund began to more carefully evaluate social

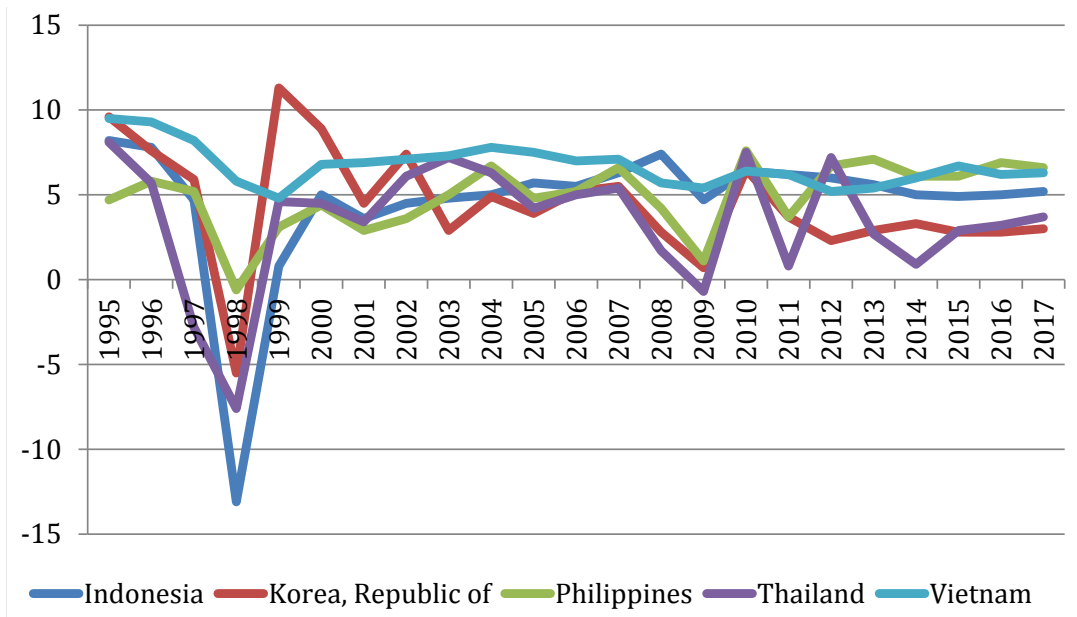

Fig. 1. The dynamics of the GDP in East Asia countries which have genuinely benefitted from the IMF loans during the Asian crisis, 1995-2017

Source: IMF database 
consequences and impact of envisaged programs on a country by country basis, with the aim to thoroughly improve the quality of its assistance in the future.

The Asian crisis of 1997-98 was a result of the combination of both IMF's failures and mistakes of respective countries wherein it mostly operated, in particular, Indonesia, Korea, and Thailand. The Fund itself acknowledged the mistakes in its policy, which exacerbated the crisis in these countries (IMF, 2003). The main failures were as follows:

- the IMF's limited financial assistance, in particular, in Thailand (only $\$ 17.2$ billion);

- the tight fiscal policy under conditions of aggregate demand worsening;

- the use of tight monetary policy in a fragile banking system, instead of introducing a moratorium and reducing the duration of this policy;

- floating exchange rate, which led to a sharp decline in the exchange rate, coupled with inefficient management of the banking sector, including the premature closure of 16 banks in Indonesia without a guarantee of return of deposits;

- excessive structural conditions beyond the limits of macroeconomic problems, in particular, in Indonesia;

- lack of premature attention to corporate debts and insolvency issues (Kawai, 2015).

It is fair to say the IMF could have offered better strategies to prevent the crisis and to overcome its impact in the countries of the region. The most important lesson learned from this financial crisis is obviously that it is always better to prevent a crisis than to deal with it, which involves the importance of enhanced macroeconomic and financial supervision. However, since crisis may arise again, the thorough crisis management system must be established and strengthened. This system should ensure on the one hand prompt and effective reaction by respective governments, and on the other hand timely provision of large-scale international assistance (through the IMF or regional development banks), which in turn will prevent the economic downturn from sharply reducing national reserves.

After the Asian crisis, it was recognized that a welldeveloped regional structure could contribute to the financial stability of the countries of the region in three ways:

- It is risky to rely only on the IMF on anti-crisis policies;

- Regional cooperation mechanisms would allow more effective prevention and management of financial risks;

- The regional basis for financial cooperation was logical, given the strong regional economic and financial interdependence of countries in the region.

Thus, the implementation of the IMF recommendations in the East Asia region had paradoxically both positive and negative impact on the countries. On the one hand, the IMF's financial measures aimed at overcoming the crisis included a waiver of a fixed exchange rate and anchoring to the US dollar; an increased refinancing rate to strengthen national currencies; holding fierce fiscal policy to reduce the state budget deficit; greater openness of markets for foreign capital for the development of competition and the internationalization of national economies, and others. On the other hand, the implementation of the IMF's recommendations adversely affected the socio-economic sphere, namely, the decline of national production, massive bankruptcies of medium and small businesses, the collapse of the health care system, rising unemployment, reducing imports, falling living standards, increasing social and political tension.

More specifically, the cooperation with the IMF has had a positive impact on the currency regimes put in place in the ASEAN +3 countries. Indeed, cooperation with the IMF, which provides funding only through existing lending mechanisms, has beneficially affected the exchange regimes of the countries involved thereby making them more flexible and not tied to national regulations. The countries most actively cooperating with the IMF continue to use the floating exchange rate (Table 2).

Table 2

Classification of exchange rate regimes in East Asia, 2017

\begin{tabular}{|c|c|c|}
\hline Country & $\begin{array}{l}\text { Exchange rate } \\
\text { regimes }\end{array}$ & $\begin{array}{l}\text { Affiliation to fixed } \\
\text { exchange rate/anchor } \\
\text { floating exchange rate }\end{array}$ \\
\hline \multicolumn{3}{|c|}{ Hard peg } \\
\hline Brunei & $\begin{array}{c}\text { Currency board } \\
\text { arrangement }\end{array}$ & SGD \\
\hline \multicolumn{3}{|c|}{ Soft peg } \\
\hline Cambodia & \multirow{3}{*}{$\begin{array}{c}\text { Stabilised } \\
\text { arrangement }\end{array}$} & \multirow{3}{*}{ USD } \\
\hline Vietnam & & \\
\hline Laos & & \\
\hline China & $\begin{array}{l}\text { Crawl-like } \\
\text { arrangement }\end{array}$ & anchor money supply \\
\hline Malaysia & \multirow{3}{*}{$\begin{array}{l}\text { Other managed } \\
\text { arrangement }\end{array}$} & \multirow{3}{*}{ anchor of monetary policy } \\
\hline Myanmar & & \\
\hline Singapore & & \\
\hline \multicolumn{3}{|c|}{ Floating regime } \\
\hline Korea & \multirow{4}{*}{ Floating } & \multirow{4}{*}{ anchor of inflation } \\
\hline Philippines & & \\
\hline Indonesia & & \\
\hline Thailand & & \\
\hline Japan & $\begin{array}{l}\text { Independently } \\
\text { floating }\end{array}$ & $\begin{array}{l}\text { Anchor of inflation (in a } \\
\text { range of } 0-2 \% \text { ) }\end{array}$ \\
\hline
\end{tabular}

Source: IMF (2016). Annual Report on Exchange Arrangements and Exchange Restrictions 2016. - P. 5-6 according to classification IMF Monetary and Capital Markets Department Revised System for the Classification of Exchange Rate Arrangements // IMF Working Paper. P. 4.

Floating currency regime is more liberal insofar it implies that the central bank does not assume any obligations to regulate or influence the formation of the 
exchange rate, such a course determined by the effect of market mechanisms and laws in the foreign exchange market (Menon, 2014). To date, only one country (Brunei) within ASEAN+3 uses the fixed exchange rate regime. Eight countries of the region have implemented so-called transitional exchange rates. De facto China has a floating exchange rate regime, and five countries, which were the largest borrowers from the IMF in the region, have de jure a floating exchange regime.

Despite the fact that IMF financial assistance helped the East Asia countries to overcome their problems with currency liquidity, to equalize the course of their national currencies, and to return them to the rails of economic growth, it is however questionable that further cooperation with the Fund will be attractive for the countries of the region "not only because it offered bitter drugs, but also due to the fact that he misdiagnosed the problem, which, in fact, later recognized himself."

At present, the IMF's activities in the region are focused on the following main aspects:

- economic monitoring and advice on macroeconomic policy. The IMF's proposals are included in the annual Regional Economic Outlook (Asia and Pacific) report showing vulnerabilities in the economies of the countries of the region;

- assistance in order to enhance the interaction between developed countries and developing countries in the region.

- cooperating with regional associations such as AsiaPacific Economic Community and ASEAN+3;

- exchange of macroeconomic information and expertise;

- participating in the Financial Sector Assessment Program established in 1999 with the goal of a comprehensive analysis of the country's financial sector;

- technical assistance, in particular, in regard to financial policy in some countries of the region;

strengthening social protection. By supporting the countries affected by the global crisis, the Fund has expanded its lending capacity and continues to seek ways to further improve the quality of its loans. Working with partners in Europe, the Fund is exploring opportunities for closer cooperation with regional funding mechanisms, including the Chiang Mai Initiative in Asia;

- exchange of knowledge, in particular, provide training and staff exchange opportunities and enhance cooperation with AMRO.

\section{Expansion of regionalism and the IMF's challenges}

The dissatisfaction of the East Asian countries with the IMF's activities during the Asian financial crisis of 1997-98, in particular, the introduction of harsh conditions for loans and ineffective actions, not only gave rise to the IMF stigma but also pushed them to a closer region-based integration. Thus, in 2000, the Chiang Mai Initiative was set up with the aim of solving short-term liquidity problems within the ASEAN+3 countries, in order to replace global financial mechanisms and/or enhance existing regional mechanisms. This mechanism was based on bilateral currency swap agreements between the central banks of the ASEAN+3 countries. But the global financial crisis of 2008 gave rise to the need to extend the initial initiative. Thus, in 2010, an agreement was reached between the ASEAN +3 countries on the establishment of the Chiang Mai Initiative Multilateralization, which was based on multilateral currency swap agreements. As a result, each ASEAN-5 can for now attract up to 22.76 billion dollars USA (Menon, 2014).

In 2011, the ASEAN+3 Macroeconomic Research Centre (ASEAN+3 Macroeconomic and Research Office - AMRO) was established initially as a private limited company and become an international organization in 2016 with its main mandate being to conduct macroeconomic and financial surveillance of global and regional economies and to contribute to early detection of risks, policy recommendations for remedies actions, and effective decision-making of the CMIM (Kawai, 2017).

Supervision is the main task of AMRO, wherein a distinction is made between supervision in peacetime and the one during the crisis. In peacetime, AMRO prepares quarterly reports assessing overall macroeconomic performance, both in the region as a whole and separately for each country. However, in a crisis period, this organization provides a report analysing the macroeconomic and financial situation in a country for the purpose of assessing the need for assistance and of monitoring the use of borrowed funds in the framework of CMIM, and also of controlling the compliance of the borrowing country with the provisions of the CMIM Statute.

Given the expansion of regional organisations but mostly because of the IMF ambiguous achievements in the region, the Fund is currently faced with serious challenges as to how to maintain its presence in East Asia. Indeed, on the one hand, the IMF's major failures during the Asian financial crisis of 1997-98, in particular, inefficient and inadequate lending programs recognized by the Fund itself, have formed a generally hostile attitude to the Fund's activities. On the other hand, the region has known significant success towards processes of regionalization, as well as sustainable economic growth. Paradoxically enough, the East Asia countries, which achieved such growth not without the contribution of the IMF, have now opted for the use and the expansion of their own IMF-independent resources, which is currently being presented in the form of CMIM. An increased competition between China and Japan as leaders in the region has given additional impetus to this process. 


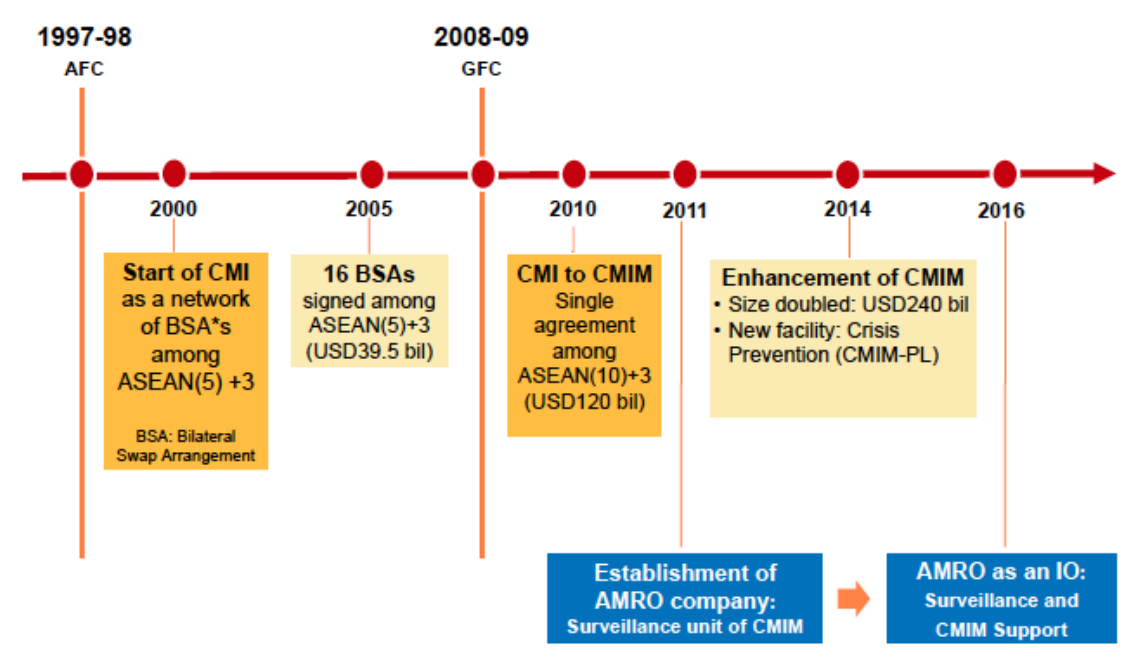

Fig. 2. Chronology of development of the CMIM from its early stage till now

However, in spite of the East Asian countries efforts to create an alternative mechanism to the IMF, the current CMIM is not likely to fully replace the Fund's resources and capacities. To date, CMIM reserves amount to 240 billion dollars of the USA only which is obviously insufficient and should a new financial crisis arise in the region, especially if the crisis spreads to several countries. For comparison, during the Asian financial crisis of 1997-98, Thailand received more than 17 billion dollars of the USA Emergency Aid. Under the current CMIM Thailand (like any other ASEAN member) will be able to receive no more than 7 billion dollars of the USA. In the same vein, Indonesia during the Asian crisis received 40 billion dollars of the USA, which is six times more than the amount that can be used within the framework of CMIM. Similarly, Korea attracted about 57 billion dollars of the USA from the IMF during the crisis, which is almost double its quotas in CMIM, namely 38 billion dollars of the USA.

In addition, there are a number of other limitations suffered from within CMIM's, namely:

(a) Although the need for monitoring economic situation and macroeconomic indicators is crucial for identifying early crisis symptoms and for an adequate assessment of the economic situation in the countries in accordance with regional economic conditions, AMRO, which carries out economic supervision in the framework of CMIM, has only recently begun to be the bona fide international organization that remains in the process of becoming (Takagi, 2016).

(b) The management of CMIM reserves is carried out by specific countries, and not in the form of contributions as it is the case within the IMF, which limits its autonomy and effectiveness in the event of a crisis. Moreover, in the case of force majeure, each member of CMIM has the right to not contribute to reserves, which limits the effectiveness of SMIs in the event of a crisis; (c) Although CMIM is funded exclusively by ASEAN+3 countries, $70 \%$ of its reserves relate to the IMF conditions that require significant structural reforms in the borrowing country, in particular, regarding the application of fiscal constraints and changes in monetary policy. As a result, should a country need to raise funds of more than $30 \%$ of the resources available to it under the SMI, it is obliged to apply simultaneously to IMF programs;

(d) The CMIM does not have its permanent secretariat, which causes uncertainty as to the procedure for activating assistance programs. Moreover, decisionmaking on the provision of assistance may take a long period of time, especially if the required amount will be more than $30 \%$ of the possible amount for the borrowing country until the IMF position is agreed upon;

(e) The CMIM does not consider the main donors as potential debtors of the resources of this initiative, namely Korea, Japan, and China, in particular as backed up by bilateral swap agreements between these countries, and the data have agreed to promote the investment of foreign reserve bodies in the form of government bonds. Thus, during the World Financial Crisis of 2008, no East Asian country used the mechanisms under the CMIM. For example, Korea and Singapore, having problems with liquidity in financial markets at the end of 2008, attracted $\$ 30$ billion through swap agreements with the Federal Reserve USA, instead of using opportunities within CMIM (Menon, 2014). Moreover, insofar the largest donors are not considered as potential debtors, it remains unclear whether the new ACEAH be able to access CMIM assistance at the event if the ACEA-5 countries' quota is insufficient as it was the case during the Asian financial crisis?

In our view, the IMF should consider taking advantage of the numerous deficiencies of the current and newly established regional financial mechanisms in order to enhance its presence in East Asia region. 
Thus, the IMF should at the least actively engage with such regional mechanisms. In this regard, it is in the best interests of AMRO itself to deeply cooperate with the IMF in order to gain necessary experience, which is a top priority for member countries. The IMF should also be more active in the region in providing technical and analytical assistance through training and joint working groups in relation to $\mathrm{AMRO}$, so as to contribute to the development of this organization.

Moreover, since the IMF has acquired broad expertise in providing technical assistance, and has significant credibility as an observer of the currency system, especially for low-income countries in the region, it should consider sharing this expertise at least until AMRO achieves similar competencies and credentials. It is true that the credibility of the IMF's independent oversight of the macroeconomic and financial health of the countries of the region cannot be easily renewed, especially in eyes of the large countries dominated by CMIM and AMRO. Nevertheless, the IMF should continue to improve and strengthen its oversight in the region in helping AMRO (for example, focusing on interregional and global ties) to maintain its unique position as an authoritative expert.

The IMF should also consider developing lending programs specifically developed for Asia in cooperation with AMRO, provided that the latter will reach the appropriate institutional capacity.

In our view, all said steps may help the IMF to restore its reputation in the region. Indeed, helping CMIM to become the driving force in the region's financial assistance (as in the case of European mechanisms) can help eliminate unpleasant memories of unsuccessful lending in the region, which was the main reason why Asian countries now reject the IMF's assistance.

In this regard, when Japan proposed to create "Asian Monetary Fund" (which remains the ambitions of Japan for the future of CMIM) in 1997, the IMF failed to support this initiative on the basis of duplication of functions and moral hazard. In our view, this position is not very constructive insofar it does not contribute to the restoration of the IMF's image in the region. Instead, the IMF should take an active stand on the proper development of further regional initiatives with the aim to subsequently gain long-term recognition and institutional influence.

To conclude, in spite of the expansion of regionalism, the IMF still remains a unique organization in terms of universality and diversity of its membership, financial resources and experience in implementing aid packages. The IMF remains to date the only international financial institution capable to face crisis process both in international and regional level. The current regional mechanisms in East Asia such as CMIM cannot be deemed fully competitive to the IMF and can only be seen as complementary to the IMF in the region.

\section{Conclusion}

The future of relations between the East Asia region and the IMF remains today quite uncertain. Although the IMF has for twenty years spelled out plans as to how to make the global financial safety net more effective through the collaboration with regional financial arrangements, its achievements in the midst of the Asian financial crisis remarkably differed from expectations. However, in our opinion, cooperation between the IMF and the East Asia region is not an ended story. Such cooperation can develop in two scenarios. First, although it is expected that Asian countries will further try to increase confidence in their macroeconomic management and financial policies through "selfsufficiency" in order to accumulate significant gold and exchange reserves, the IMF should still maintain its presence in the region in contributing to regional cooperation mechanisms given its experience and expertise. Second, the IMF should consider revising its policies so as to allow at least the leaders of the East Asia region being more significantly involved in managing the Fund. This does not necessarily mean the need for Asian countries to benefit from the IMF's financial resources, but will compensate the lack of presence in the Fund and will furthermore strengthen their positions in decision-making processes within this institution. This will also be beneficial for the IMF insofar it will help the Fund to restore its reputation in the region. In this regard, the 2010 reform has partly changed the situation at the IMF with respect to the percentage of votes in Asian countries, especially China. Thus, the shares of these countries at the IMF within the reform have doubled, to 6.09 percent, while the share of ASEAN+3 countries has increased to 18.21 percent, exceeding the US by 16.52 percent. Therefore, ASEAN +3 countries should consider acting as a bloc, which will allow them to significantly increase their influence on IMF management and decision-making.

\section{References:}

International Monetary Fund. (2017). Sustainable Growth: Short-term Recovery, Long-term Challenges. Washington, DC.: IMF, 304.

World Bank. (2016). "Reducing Vulnerabilities." East Asia and Pacific Economic Update. Washington, DC.: World Bank, 186. doi: 10.1596/978-14648-0991-0.

Asian Development Outlook Update. (2017). Sustaining Development Thought Public-Private Partnership. Manila: $\mathrm{ADB}, 243$. 
Svedentsov, V.L. (2017). New International Development Banks and the Interests of Russia. The World of New Economy, 1, 55-59.

Arapova, E. Y. (2015). Economic integration in East Asia. Retrospective analysis and future opportunities. Moscow: Prospect.

Berendser, B. (2013). Asian tigers, African lions: comparing the development performance of Southeast Asia and Africa. Leiden, Boston, Brill.

Takagi, S. (2016). The IMF and East Asia: the legacy of the crisis and actions for the future. In S. Armsrong and V. T. Thanh (Eds.) International Institutions and Asian Development (74-96). London: Routledge.

Kawai, M. (2015). From the Chiang Mai Initiative to an Asian Monetary Fund. ADBI Working Paper 527. Tokyo: Asian Development Bank Institute.

Menon, J. \& Hill, H. (2014) Does East Asia Have a Working Financial Safety Net? Asian Economic Journal, 28 (1), $1-17$.

Kawai, M. (2017). Asia's Financial Stability as a Regional and Global Public Good. In A. Estevadeordal \& L. W Goodman (Eds.), $21^{\text {st }}$ Century Cooperation (312-335). London: Routledge.

Andone, I. \& Scheubel, B. (2017). IMF Stigma: The Role of Own and Neighbours' Experience. CESifo Working Paper Series No. 6399, 63. 